Yakpo, Kofi. 2020. Sociolinguistic characteristics of the English-lexifier contact languages of West Africa. In Norval Smith, Tonjes Veenstra \& Enoch Oladé Aboh (eds.), Advances in contact linguistics: In honour of Pieter Muysken (Contact Language Library 57), 61-84. Amsterdam: John Benjamins. https://doi.org/10.1075/ coll.57.02yak. Author manuscript version.

\title{
Sociolinguistic characteristics of the English-lexifier contact languages of West Africa
}

\author{
Kofi Yakpo \\ The University of Hong Kong
}

This chapter provides a comparison of key sociolinguistic characteristics of Nigerian Pidgin, Cameroon Pidgin, Ghanaian Pidgin English, Pichi (Equatorial Guinea) and Krio (Sierra Leone). In the past few decades, these African English-lexifier contact languages (AECs) have seen an exponential growth in speaker numbers and an expansion into domains once reserved for English and non-creole African languages. All AECs nevertheless still struggle with a low sociolinguistic prestige and the absence of corpus and status planning initiatives by state actors. Overall, the potential of these languages remains relatively untapped across the region for education, political participation, economic, and cultural activity. At the same time, the impact of the AECs on smaller languages through contact and shift to the AECs is also likely to make itself felt in coming decades.

Keywords: English-lexifier creoles, language contact, language policies, language ideologies, West Africa, sociolinguistic domains

\section{Introduction}

If Pieter Muysken's early research in creole and contact linguistics was dominated by formal approaches (e.g. Muysken 1981a, 1981b; Muysken \& Smith 1986), his work in the last two decades or so has been thoroughly interdisciplinary, integrating language typology, psycholinguistics, historical linguistics and sociolinguistics (e.g. in the "contact scenario" framework; cf. Muysken 2008). Through his work, he has also supported language vitalization, awareness-building, and information dissemination activities on the Indigenous languages of the South American Andes region (e.g. through work on the four-volume Crevels \& Muysken 2009). With his undogmatic and holistic approach, Pieter has always been a step ahead in foreseeing 
the necessity to integrate creole linguistics into linguistic typology (e.g. Yakpo \& Muysken 2017), areal linguistics (Muysken 2008; Muysken \& Smith 2015), historical linguistics (e.g. van Sluijs, van den Berg \& Muysken 2016) and sociolinguistics. Current societal trends show the necessity for a broader perspective. A tectonic demographic shift is underway on the African continent, entailing a corresponding growth in speaker numbers of the Englishlexifier contact languages of West Africa, and foreseeable changes in their social functions and uses.

The population of Nigeria, where Nigerian Pidgin, the largest English-lexifier contact language on the globe is spoken, is projected to reach about 750 million in the next eighty years (United Nations 2017:21). In view of such demographics, it is possible that the combined speaker numbers of English-lexifier contact languages (AECs) in Africa and the Caribbean will reach half a billion by 2100, making AECs the most widely spoken African language continuum, and one of the largest language clusters of the world in speaker numbers by the turn of the 22nd century. The implications of the status and uses of these languages for education, political participation, economic development, cultural expression and linguistic diversity, language contact and change, are therefore highly significant.

In this chapter, I attempt to contribute to a better understanding of these societal dynamics. I do so by providing a first comparative view of the sociolinguistic situation of the five major African AECs: Cameroon Pidgin, Nigerian Pidgin, Pichi (Equatorial Guinea), Krio (Sierra Leone), and Ghanaian Pidgin English (Ghana). I characterise the respective speaker communities, identify domains of use and address critical aspects of language policies and language ideologies.

In spite of their substantial expansion as first and second languages, the African AECs have received little attention from state institutions. The uses of these languages differ across the five countries. Their status, however, shows strong similarities. What unites all five countries is the general reluctance to furnish organised state responses to linguistic diversity on the one hand, and the presence of largely "exoglossic" (Heine 1992) language policies on the other. Such policies exclusively rely on a colonial language in official functions, privileging the use of English and Spanish (the latter for Equatorial Guinea) in formal domains including administration and the educational system. On a whole, policy makers have not responded to the possibilities that the emergence of the national AEC varieties as important lingua francas have raised for access to formal education and literacy, cultural vibrancy, nation-building, political participation and economic growth, and the economic and political integration of West Africa.

The structure of this chapter is as follows: In Section 2, I provide an overview of the English-lexifier contact languages spoken West Africa. In Section 3, I provide 
a comparative perspective by looking at the speaker communities, language uses and domains, and language policies vis-à-vis Nigerian Pidgin, Cameroon Pidgin, Krio (Sierra Leone) and Ghanaian Pidgin English. Section 4 concludes this article. Where not indicated otherwise, the observations and data stem from many years of research throughout West Africa. This data consists, among other genres, of many hours of recorded conversations on a diverse range of topics including views on grammar, language attitudes and uses.

\section{The English-lexifier contact languages of West Africa}

In the following, I use the term "(Afro-Caribbean) English-lexifier contact languages" (henceforth AECs) to designate the chain of English-lexifier contact languages spoken in the Americas and in Africa (also referred to as Afro-Caribbean English-lexifier Creoles, cf. Faraclas 2004; Yakpo 2012a; and Atlantic English-lexifier Creoles, cf. Arends, Muysken \& Smith 1995). The evidence that these languages owe similarities between each other to a common ancestry in one or several proto-languages spoken in the Eastern Caribbean in the early 17th century, and/ or along the West African coast is compelling (Hancock 1987; Smith 2015), even if the exact historical details are yet unclear. The evidence for the relatedness of the African AECs is even more convincing (Huber \& Görlach 1996; Huber 1999, 2000). The African AECs are characterised by a large number of lexical, structural, and phonological similarities (cf. Yakpo 2012b, 2013b, 2019).

AECs serve as the established community languages and L1s to the majority populations of various Caribbean nations, among them Jamaica, Guyana, Suriname, and Trinidad \& Tobago. The African AECs, however, have proportionally much larger L2 (or better, LX for "additional language") than L1 communities. Differences in the proportions of L1 and L2 speakers between West Africa and the Caribbean have prompted some sources to give the label "pidgincreole" to West African AECs like Nigerian Pidgin and Ghanaian Pidgin English (e.g. Bakker 2008; Corum 2015; Fonka 2016). I, however, dispense with the term "pidgincreole" in this chapter. There has not yet been a systematic attempt to show that the predominant use of the African AECs as L2s has any structural-lexical ramifications. What we instead find are very stable grammatical systems that do not show out-of-the ordinary features distinguishing them from other languages spoken alongside them. I therefore settle for "(Afro-Caribbean) English-lexifier contact languages" ( in this chapter.

The following table provides estimated speaker numbers of the AEC varieties of West Africa and the Caribbean (cf. Yakpo 2016a): 
Table 1. Speaker numbers of Afro-Caribbean English-lexifier contact languages

\begin{tabular}{llll}
\hline Language & Country spoken & Speaker estimate & Sources \\
\hline Nigerian Pidgin & Nigeria & $75-80$ million & Ihemere 2006 \\
Cameroon Pidgin & Cameroon & 10 million & Lewis, Simons \& Fennig 2013 \\
Krio & Sierra Leone & 6 million & Finney 2011 \\
Aku & Gambia & 14,000 & Juffermans \& McGlynn 2010 \\
Ghanaian Pidgin & Ghana & 5 million & Huber 2013 \\
English & & & \\
$\begin{array}{l}\text { Pichi } \\
\text { Caribbean } \\
\text { (combined) }\end{array}$ & Equatorial Guinea & $100-150,000$ & $\begin{array}{l}\text { Yakpo 2013b } \\
\text { Total speaker no. }\end{array}$ \\
\hline
\end{tabular}

Based on estimated speaker numbers, the different varieties of AECs together count around 110 million speakers in Africa and the Americas. The AECs form the largest linguistic continuum of West Africa, before the two largest indigenous international languages of West Africa, the Maninkakan-Bamanankan-Jula (Manding) cluster (at least 20 million speakers, cf. Vydrin 2013: 76) and Hausa (presently significantly more speakers than the figure of 40 million given in (Newman 1987: 621). It is also almost certain that the speaker numbers of the African AECs surpass those of the colonial official languages of the region, English, French, Portuguese, and Spanish put together. For example, Adegbija (2004: 195) gives the figure of twenty percent of speakers of (Nigerian) Standard English over the total population of Nigeria, without, however, providing further details about the nature of "Standard" English in the country, nor about the relationship between competence in English and in Nigerian Pidgin.

In my experience of observing and participating in interactions between AEC speakers from different West African countries, mutual intelligibility is very high. There is, however, a split between Krio and its offshoots Pichi and Aku on the one hand, and Ghanaian, Nigerian and Cameroon Pidgin on the other, which can be argued for on phonological and structural grounds (Yakpo 2013a, for a comparison of selected features of the West African AECs). Mutual intelligibility is lowest between Pichi (Equatorial Guinea) and all other West African AECs. This is a consequence of the unique trajectory of Pichi: It has been isolated from its lexicon-providing language English for two centuries and therefore escaped lexical and structural convergence with English (cf. Yakpo 2017). It has also developed phonological idiosyncrasies due to adstratal influence from the Bantu language Bubi (Yakpo 2013b: 287-90), and has been influenced extensively by Equatorial 
Guinea's colonial and official language Spanish (Yakpo 2009b, 2018). I show in the next section that the linguistic ecologies the five AECs are spoken in are characterised by both similarities and differences.

\section{The sociolinguistic situation of the West African AECs}

I will now provide an overview of the status quo of the five largest AECs of West Africa, namely Nigerian Pidgin (Nigeria), Cameroon Pidgin (Cameroon), Krio (Sierra Leone), Ghanaian Pidgin (Ghana) and Pichi (Equatorial Guinea). Aku, an offshoot of Krio spoken in Banjul, the capital of The Gambia, has been excluded because there is very little sociolinguistic and linguistic data available. I look at the nature of the speaker communities, identify domains of use, and describe the status of these languages as reflected in language policies in these five countries. The situation of these languages is similar in a number of respects. One of them is their impressive expansion and their conquest of domains once reserved for English and non-creole African languages, such as, for example, media and broadcasting, religious practice, and basic literacy teaching. At the same time, all five languages still struggle with similar prestige problems, and ideas about the inferiority of these languages (to both European and other African languages) are still being reproduced and passed down in variations and gradations by post-colonial intellectual elites (for the situation in the Caribbean, cf. Devonish 1986, 2010).

\subsection{Nigerian Pidgin}

Nigeria is of pivotal importance when assessing the significance and status of the West African AECs. With 70-80 million speakers at the very least, Nigerian Pidgin (also referred to by many Nigerians as "Naija") is the largest European-lexifier contact language on the globe (Faraclas 2013: 176). It is probably the only Nigerian language that most Nigerians can communicate in to some degree. In the West African subregion, Nigeria has been at the forefront of status and corpus planning for its autochthonous languages, introducing them into school and university curricula as well as officially declaring Hausa, Yoruba, Igbo as languages of parliamentary debate in the 2nd Republic Constitution of 1979 (cf. Adegbija 2004). Today, the country has, by comparison with other African nations a relatively vibrant media, music, film and print output in its African languages. How is Nigerian Pidgin faring in this context?

Nigerian Pidgin is probably the most widely used language in the media besides English. Knowledge about the language has been carried far beyond Nigeria's 
borders, through the country's burgeoning pop music industry and its presence and use, often in alternation with English and other languages of Nigeria, in radio programming, and in "Nollywood" films, produced by the country's prolific and internationally successful film industry. ${ }^{1}$ Nigerian Pidgin has also been used in literature in various forms, ranging from dialogues in novels and cartoons, to poetry and plays (e.g. in a recent Nigerian Pidgin adaptation of Romeo and Juliet by Bernard Ogini, see Gift 2019). In 2017, BBC Africa began a news service featuring print and audio-visual content in (Nigerian) Pidgin, largely produced by Nigerian journalists, (see <https://www.bbc.com/pidgin $>$. The spelling used is etymological, and English-oriented for words not derived from English, thus reiterating long-standing practice in the region by literate Pidgin speakers in spontaneous graphicisation found in print media, books, letters, and more recently on social media.

Nigerian Pidgin has also been enjoying increasing recognition by intellectuals, both for its immense practicality as a means of communication in Nigeria, and for its unifying potential in being less loaded with ethnic affiliation than other languages in a nation, in which ethnicity is highly politicised (cf. e.g. Momoh \& Adejumobi 2002 for an overview). The foundation of the Naija Langwej Akademi (Academy for Nigerian Pidgin) in 2010 ushered in academic involvement in corpus and status planning initiatives independently of state support, including the promotion of the glossonym "Naija". A practical standard orthography was also recently developed by the Akademi, which has the potential to serve as a regional standard for the graphicisation of other West African AECs, see <https://www. ifra-nigeria.org/naija-corner/naija-languej-akedemi $>$. Unfortunately, neither this orthography nor previous ones (e.g. Faraclas 1986) have been acknowledged and accepted outside academia, nor even by the media, as the BBC experience mentioned above shows.

Nigerian Pidgin is an important business language in Nigeria's "informal” sector, including individual, small and medium-sized businesses both within Nigeria's borders and in trans-border commerce with countries in the region including Cameroon, Benin, Togo, and Ghana. Equally, Nigerian Pidgin has long been used as a language of interaction and command in military and police barracks, which have been focal points in the spread of the language into Nigeria's urban areas.

1. The use of Nigerian Pidgin in pop music increased exponentially after Nigerian independence in 1960. People in other parts of Africa and the world were familiarised with it through international hits like sweet mother by Prince Nico Mbarga (1976) <http://youtu.be/3mecNrIaWOA $>$, and the complete works of Fela Kuti, e.g. colonial mentality (1977) <http://youtu.be/ WKm7tWTnfnU>. Today, songs sung in Nigerian Pidgin dominate Nigeria's and West Africa's pop music scene and are increasingly penetrating the global pop music market, see e.g. Tekno's 2016 world hit Pana $<$ https://youtu.be/8YhAFBOSk1U>. 
Last but not least, Nigerian Pidgin has a growing L1 community, particularly in the highly multilingual Delta region in the south of the country (Adegbija 2004: 226).

Nevertheless, there has so far been no state recognition of Nigerian Pidgin, nor any other serious attempts at status and corpus planning (Agheyisi 1988; Igboanusi 2008). As a consequence, Nigerian Pidgin is the only large Nigerian language to yet have no officially recognised orthography (Ojarikre 2013), nor regulated presence in the educational system or other institutional contexts (Gani-Ikilama 1990). That said, Nigerian Pidgin has served as a language in grass-roots literacy campaigns (Faraclas 1986), and is used in proselytization activities by Christian groups (for a translation of the Christian New Testament into Nigerian Pidgin, cf. <http:// nigerianpidgin-bible.yolasite.com $>$. Nigerian Pidgin is also used by Nigerians in interactions with the administration and is hugely popular as a youth sociolect and language of identity for Nigerians of all class backgrounds and age groups. Consequently, a closer look reveals a broad range of attitudes towards Nigerian Pidgin, reflecting the kind of ambivalence to the language found towards other AECs; an ambivalence that reflects the tension between practicality and the identitarian value of Nigerian Pidgin on the one hand, and the reproduction of the cultural and political legacy of colonial rule on the other, with its privileging of English as the ne plus ultra of upward social mobility.

\subsection{Cameroon Pidgin}

The sociolinguistic situation of Cameroonian Pidgin (also referred to as "Kamtok" by some academics and language activists, cf. Ngefac 2010: 152, for the rationale in choosing this designation) is very similar to that of Nigerian Pidgin. Cameroon Pidgin is probably the most widely spoken language of Cameroon, although national figures are difficult to come by due to the absence of comprehensive linguistic surveys. Extrapolations of speaker numbers range between a quarter to half of the Cameroonian population, hence up to 10 million (cf. e.g. the entry "Pidgin, Cameroon" in Lewis, Simons \& Fennig 2013). Cameroon Pidgin is the first and dominant language of a growing proportion of inhabitants of the so-called "anglophone" or "English-speaking" provinces of western Cameroon (Schröder 2003: 82ff.). The spread of Cameroon Pidgin into the "francophone" or "French-speaking" provinces of Cameroon has prompted Cameroonian scholars and lay people to emphasise the value of the language in bridging the political divisions between "anglophone" and "francophone" Cameroon (e.g. Neba, Chibaka \& Atindogbé 2006).

The expansion of Cameroon Pidgin has followed similar pathways to Nigeria. The domains of use of Cameroon Pidgin have been continually expanding since independence, from market-place communication, via use in popular music and 
oral genres like Cameroonian pop music, comedy, radio programming, advertising (Schröder 2003: 123ff.; Anchimbe 2013: 172-73), to its appropriation as a language of youth identity and counterculture on school and university campuses, despite constant attempts to ban its use in these institutions (Alobwede D'Epie 1998). Factors such as these have led to Cameroon Pidgin increasingly penetrating the traditionally "francophone" cities of central and south-eastern Cameroon beyond Douala, one of its traditional strongholds in the "French-speaking" part of the country. According to Mbangwana (1983) the number of four-year olds using Cameroon Pidgin in 1983 as an L1 ranged between 20-30\% in the major urban centres of "anglophone" Cameroon (Bamenda, 22\%, Buea, 26\%, Limbe, 31\%). In a more recent survey by Schröder (2003: $83 \mathrm{f} \mathrm{f}$.) these percentages have risen considerably (Bamenda, 36\%, Buea, 42\%), and show surprisingly high double digits of Cameroon Pidgin L1 speakers in Cameroon's capital Yaoundé (30\%) located in the "francophone" heartlands of the country.

Cameroon Pidgin has conquered a broad range of additional domains in the last few decades, halting only before the most formal, institutionalised ones: written literary production, administrative and legal writing, in-class interaction, and big business interaction in the formal sector of the economy (Schröder 2003: 181; Anchimbe 2013: 176ff). This notwithstanding, an institutional recognition of Cameroon Pidgin as a language in its own right and a suitable subject of language policy is not on the horizon. There is a relatively large body of descriptive work on Cameroon Pidgin (among which major works like Kouega 2008; Nkengasong 2016; Ngefac 2016; Ayafor \& Green 2017), as well as Christian missionary initiatives, e.g. the Cameroon Pidgin New Testament (Molindo 1996). As is the case with the other AECs of West Africa, substantial sections of the traditional intellectual and political elites of the country see Cameroon Pidgin as a deficient form of English. A recurring theme in the discourses on Cameroon Pidgin is its supposed potential to hamper the acquisition of standard English during secondary and tertiary education (Anchimbe 2013: 11-12).

In Cameroon, we therefore find the usual ambivalence towards the language as in Nigeria. On one side, Cameroon Pidgin serves as a vehicle of regional identity (i.e. the language of unity of the linguistically highly diverse two "anglophone" provinces of Cameroon) and urban identity. On the other side, many Cameroonians, and members of the elite in particular, reproduce a cultural, political, and economic system that privileges English (and French) at the expense of Cameroon Pidgin and other African languages in order to be socially and economically successful. On such an ideological and political backdrop it is unlikely that any form of officialising policy towards Cameroon Pidgin will be undertaken in the near future, while the language continues to naturally expand its domains of use. 


\subsection{Krio (Sierra Leone)}

Krio is spoken by the Krio people, to whom it has served as the primary language of community and identity since the emergence of Krio in the late 18th and early 19th century. Through the 19th century presence of Krio people along the west coast of Africa, the Krio language deeply influenced, merged with or replaced pre-existing English-lexicon contact languages in Ghana, Nigeria and Cameroon (cf. e.g. Huber 1995; Huber \& Görlach 1996). Through the course of time, Krio has been continuously acquiring additional L1 speakers of diverse ethno-linguistic backgrounds in Freetown, the capital of the country and traditional settlement area of the Krio people. $^{2}$ The number of L1 Krio speakers is pegged at somewhere between five and ten per cent of the country's population of six million, but Krio is also the most widely spoken L2 in Sierra Leone, serving as the primary interethnic vehicular language, with a high degree of competence ascribed to virtually the entire population of the country (Finney 2013: 157).

Sierra Leone Krio boasts the longest history of corpus and status planning of all African AECs. The language has enjoyed a comparatively high prestige compared to the other AECs because it has been associated with the Krio ethnic group, which dominated Sierra Leonean society under British colonial rule in the 19th and 20th centuries. Krio therefore received more attention by Sierra Leonean and foreign linguists than other AECs of the region, extending to socio-historical and descriptive work (e.g. Berry 1961; Jones 1968; Hancock 1971 for some earlier works), and the most extensive dictionary of an African AEC to date (Fyle \& Jones 1980). The decades after independence in 1961 until the 1991-2002 civil war saw a significant development of Krio literature, chiefly in the form of theatre plays and short stories (cf. e.g. Decker 1988) as well as a recent bible translation (Bible Society in Sierra Leone 2013). Citizens' initiatives at uplifting the status of Krio coincided with state and donor-supported status planning for Krio and other languages of Sierra Leone (i.e. Mende, Temne, Limba) being targeted for inclusion as a subject into school and university curricula (cf. e.g. Anonymous 1984). The relatively high status of Krio can be seen from the fact that the Universal Declaration of Human Rights was

2. The concept of an L1 and L2 is, of course, a problematic one in the multilingual societies of West Africa. I employ the term in this section and following ones on the basis of usage as one of several primary languages of socialisation inside and outside of the family from early childhood onwards. According to this definition, an L2 is any language mainly acquired outside of the home, and at later points in life. In the West African contexts I am familiar with, the acquisition of L2s in addition to (various) L1(s) often begins on the cusp of, or during adolescence, with the onset of greater personal mobility and the broadening of personal networks of an individual speaker. 
translated into Krio by a state body, the National Commission for Democracy and Human Rights of Sierra Leone.

Much of the administrative and educational infrastructure of Sierra Leone was wiped out during the civil war. But internal displacement from the linguistically more homogenous rural areas during the war, and settlement, population mixture, and accelerated urbanisation in the post-war period have favoured the expansion of Krio as an L2 lingua franca. An increasingly positive attitude towards Krio has concomitantly developed (Finney 2013: 158). The language is nowadays also widely used in broadcasting, TV, advertising, pop music and for civic and health education. Besides the increased practical value of Krio as a nation-wide medium of communication, the popularity of Krio is also due to its relative identitarian "neutrality", a characterisation that is often also heard with respect to the other African AECs. The lingua franca status of Krio as everybody's language is perceived to transcend the ethnic divisions fomented by politicians and military leaders before and during the civil war. Krio did not always have a more neutral position in the country. For the longest time after the colonization and creation of Sierra Leone by the British, the country was dominated politically, economically and intellectually by the numerically small Krio people. Krio hegemony, however, saw a steady decline after Sierra Leone's independence, accompanied by the rise of ethnically more heterogeneous elites (Wyse 1991), thereby possibly contributing to a change in attitudes towards Krio. Today, Krio is spoken as an L1 or L2 by virtually the entire population of the country, thereby even outranking the proportion of Nigerian Pidgin speakers in Nigeria.

In sum, Krio differs quite markedly from the other West African AECs in a number of key socio-linguistic characteristics. Of course, negative attitudes towards Krio still persist due to similar dynamics as with the other West African AECs. Krio nevertheless has a higher prestige than the other AECs, has seen some degree of official recognition and has been the subject of policy making. Krio is also more widely used than other African AECs as a written medium both in secular and religious writing, and with a widely accepted standard orthography. This makes Sierra Leone a potential benchmark for future status and corpus planning initiatives in the other countries discussed in this chapter.

\subsection{Ghanaian Pidgin English}

If the status of Krio in Sierra Leone is relatively high, the opposite can be said of that of Ghanaian Pidgin English. Ghanaian Pidgin English is not officially recognised in any form, neither legal, nor de facto. It is less present in the audio-visual media, or in advertisements than the other AECs (except perhaps Pichi, see 3.5). 
Even in pop culture, where the AECs have probably made their greatest advances outside of the interpersonal domain in all AEC-speaking countries, Ghanaian Pidgin English has made less dramatic an incursion than in Nigeria. The majority of songs released in Ghana's highly productive pop music industry are still sung in Akan even if Ghanaian Pidgin English is omnipresent in Hiplife, the Ghanaian offshoot of Hip Hop music (e.g. the complete works of Fokn Bois, cf. <http:// youtu. be/R_YsQK2Yo3c>) and gaining ground in other pop genres, too.

A specific set of circumstances renders Ghana a special case with respect to the status and uses of the AEC variety spoken in this country. Firstly, Ghanaian Pidgin English is a language that has been classified as a pidgin (hence a contact language without L1 speakers) rather than a creole (a contact language with at least some L1 speakers) (Huber 1995; Dako 2002). Ghanaian Pidgin English is indeed used in fewer domains than the other three AECs treated above. The lack of sociolinguistic data, however, makes it impossible to determine whether Ghanaian Pidgin English does not also serve as an L1. I have anecdotal evidence for Ghanaian Pidgin being used as a language of the home for vertical communication between fathers and sons, and the language is certainly used for horizontal communication between couples as well as siblings in some urban homes from school-going age on-wards. All researchers working on Ghanaian Pidgin English, however, agree that the language does not serve as the primary language of any ethnic community or region of Ghana.

The absence of a deep social entrenchment may be the reason why Ghanaian Pidgin speakers appear to draw more extensively than those of other African AEC varieties, on lexical items, idioms, and grammatical structures from Ghanaian colloquial English and Ghanaian languages (see e.g. Osei-Tutu 2016), why they practice a high degree of conventionalised codeswitching with Ghanaian English and other Ghanaian languages, and why Ghanaian Pidgin appears to have incorporated a higher proportion of youth language lexicon, Nigerian Pidginisms, Jamaicanisms, African-American Englishisms, and international English slang items into its core system. ${ }^{3}$

3. We find, for example, the ubiquitous term of address chale [t $\mathrm{t} a \mathrm{l}$ lé] 'dude, man', a shibboleth for Ghanaian Pidgin speakers. The term goes back to the North American slang term of address charlie. It is unclear how and when it arrived in Ghana. Nigerian Pidgin has provided the modal question particle àbí (Nordén 2016: 22), and the (pseudo-)Jamaicanisms wànà '1 PL.Poss' and dغ̀mà '3PLPOss' have been fully integrated into the pronominal system of the Student Pidgin variety of Ghanaian Pidgin English, and have spread to other groups of speakers. For the presence of youth language features in Ghanaian Pidgin, see Osei-Tutu (2008). 
For most Ghanaians the encounter with Ghanaian Pidgin English begins during late childhood and adolescence, a time when the language becomes the primary medium of peer group interaction in schools, and in boarding schools in particular (Dako 2002). Ghanaian Pidgin English enjoys popularity with pupils as the icon of a linguistic counterculture against the top-down enforcement of English in classrooms. The language serves as a marker of youth identity and self-identification, increasingly too for girls and young women (Dako 2013). The tendency to use Ghanaian Pidgin English in peer group interactions continues unabated in tertiary institutions, where most students live together in on- and off-campus boarding houses. For the generation that introduced Ghanaian Pidgin English into educational institutions in the 1970s and 80s, and carried it back into their families and neighbourhoods, the language still functions as a "youth" sociolect, and marker of group identity in spite of the now advanced age of these speakers. Due to its adoption and creative expansion by the urban secondary and tertiary educated class of Ghana, a fluent and versatile command of Ghanaian Pidgin English has, paradoxically it may seem, become a marker of membership in the more affluent socio-economic class. At the same time, mastery of the language also provides these very speakers with an important linguistic resource to navigate the "informal" economy in a society characterised by economic uncertainty.

During several research trips to Ghana between 2016 and 2019, I observed Ghanaian Pidgin being spoken in many more areas and domains than I had previously thought, and by all generations but the most elderly, and across all social classes and in contexts where the interactants had shared competence in other Ghanaian languages. I heard Ghanaian Pidgin being used among young men in cities and towns all over the country, and in remote rural areas, including my own village Kute Buem, an isolated hamlet in the Volta Region. In a country characterised by rural-urban (circular) migration, competence in Ghanaian Pidgin signals acquaintance of, and experience with urban life in the capital Accra and other cites, which can constitute important social and economic capital in rural areas.

This development is interesting because Ghanaians of different linguistic backgrounds can usually resort to languages other than Ghanaian Pidgin English in order to communicate effectively. The numerical preponderance of Akan speakers in Ghana has favoured the expansion of Akan as an L2 lingua franca and koine since Ghana's independence (Yankson 2018).The usage domains of Akan have expanded dramatically since then and it is increasingly penetrating high domains. There are, for example, Akan-only TV channels and radio stations, and there is extensive Akan-English codeswitching on many primetime TV and news shows. On such a background, it is very likely that Akan and other large Ghanaian languages (e.g. Ewe in the Volta Region and Hausa in the northern regions of the country) will continue 
to play a lingua franca role, but Pidgin English will make itself increasingly felt in the Ghanaian linguistic landscape.

\subsection{Pichi (Equatorial Guinea)}

Up to seventy per cent of the population of Bioko island, hence up to 150,000 speakers regularly use Pichi at various levels of nativisation and in various multilingual and multilectal constellations in and outside their homes (Yakpo 2013a: 194). The speaker community of Pichi is ethnically and culturally diverse and includes the traditional creole community of Bioko (the "Fernandinos", see Lynn 1984) as well as ethnically mixed families. The largest numbers of speakers are probably people who self-identify as ethnic Bube, but have shifted to Pichi as a primary language (referred to as "nuevos criollos" [New Creoles] by Morgades Besari (2011); see also Bolekia Boleká 2005). Pichi is the most widely spoken African language on Bioko, while Fang is used by probably ninety per cent of the population in the continental part of the country. Both Pichi and Fang probably also serve as the most important international languages to common Equatoguineans. Pichi has served as the primary language of interaction for Equatoguineans in dealings with Nigerians, Cameroonians and Ghanaians since at least the beginning of the twentieth century (cf. Lipski 1992). Likewise, "Fang", a term for a continuum of closely related, mutually intelligible lects, serves as an international language across continental Equatorial Guinea, southern Cameroon, Gabon, and the border zone of The Republic of Congo (see Perrois 1972: 102-105, on the linguistic relations between these varieties).

The political and legal context differs markedly from the realities of language use in Equatorial Guinea. The constitution of Equatorial Guinea (Article 4) declares Spanish, French and Portuguese "official languages" while the "indigenous languages are recognised as an integral part of the national culture". Three European languages are therefore given legal recognition as languages of government business and officialdom even if neither of the co-official languages French and Portuguese play any significant role for everyday communication among Equatoguineans. From the primary to the tertiary levels, instruction is given exclusively in Spanish, the only de facto official language of the country. There is no legally or politically defined role for education in the African mother tongues of the majority of Equatoguinean children (Yakpo 2016a). Equatorial Guinea therefore features an overtly exoglossic language policy that uniquely privileges the colonial language Spanish. Nevertheless, Fang in particular, is increasingly heard in semi-formal contexts, and Fang and other African languages have slots in national radio programming. Some of the indigenous languages of the country have more or less 
widely accepted known orthographies, and there is a modest religious literature (e.g. Asociación Cristiana de Traducciones Biblicas n.d.). Pichi is, in contrast, absent from print, online and audio-visual media, and is not normally employed in church, larger social gatherings (e.g. weddings) or other semi-formal settings. Pichi is equally very little present in contemporary pop music culture, a somewhat surprising fact in view of the prominence of music sung in Nigerian Pidgin in the soundscape of Malabo. Interactions in Pichi are therefore almost entirely relegated to the interpersonal domain. Finally, prior to the publication of Yakpo 2009a and 2010, the only existing descriptive work available was a modest grammar sketch and wordlist by de Zarco (1938).

In Equatorial Guinea, as in other African countries, a complex conglomerate of ideological, political and economic factors, socio-cultural dependence on the former coloniser, elitism, a lack of political vision among the ruling elites, weak state institutions and the lack of resources, administrative and technical expertise seems to be responsible for the neglect of African languages by state institutions, and the continuation of colonial language policies. All the indigenous languages of Equatorial Guinea therefore suffer from this status quo. But prevailing linguistic ideologies contribute to the particularly disadvantaged position of Pichi in the linguistic setting of Equatorial Guinea (see Yakpo 2016b).

\subsection{Summary of findings}

In the preceding sections, I have attempted to describe certain sociolinguistic characteristics of the speaker communities of the five major African AECs. Table 2 below provides a summary of these characteristics.

The Krio language on the very right of Table 2 features the largest proportion of speakers in the country it is spoken in (95\% of the population of Sierra Leone is estimated to speak Krio). Krio has also conquered the largest number of domains of use of all AECs and has been the subject of status and corpus planning to a higher degree than the other languages. Pichi occupies the opposite end of the cline, with a relatively small proportion of speakers, although Pichi probably is the second largest African language of Equatorial Guinea. Pichi also has the lowest official status and domains of use outside of the interpersonal sphere. Nigerian Pidgin and Cameroon Pidgin fall in the middle range of the spectrum, with proportions of speakers significantly lower than Krio but still substantial. Both languages are probably spoken by a larger percentage of people in their respective homelands than any other African language. Nigerian Pidgin and Cameroon Pidgin are also similar in their sociolinguistic profile in that both languages are used in all domains but the most formal types of (written) literature. Nevertheless, Cameroon Pidgin 
Table 2. Comparison of selected socio-linguistic characteristics of West African AECs

\begin{tabular}{|c|c|c|c|c|c|c|c|}
\hline & Context & Characteristic & Pichi & $\begin{array}{c}\text { Ghanaian } \\
\text { Pidgin }\end{array}$ & $\begin{array}{c}\text { Cameroon } \\
\text { Pidgin }\end{array}$ & $\begin{array}{c}\text { Nigerian } \\
\text { Pidgin }\end{array}$ & Krio \\
\hline \multirow[t]{4}{*}{ a. } & \multirow{4}{*}{$\begin{array}{l}\text { Speaker } \\
\text { community }\end{array}$} & L1 community & $\sqrt{ }$ & $x$ & $\sqrt{ }$ & $\sqrt{ }$ & $\sqrt{ }$ \\
\hline & & $\begin{array}{l}\text { More L2 than L1 } \\
\text { speakers }\end{array}$ & $\sqrt{ }$ & $\sqrt{ }$ & $\sqrt{ }$ & $\sqrt{ }$ & $\sqrt{ }$ \\
\hline & & $\begin{array}{l}\text { Ethnic community } \\
\text { language }\end{array}$ & $\sqrt{ }$ & $x$ & $\sqrt{ } / x$ & $\sqrt{ } / x$ & $\sqrt{ }$ \\
\hline & & $\begin{array}{l}\text { Proportion of (L1 \& L2) } \\
\text { speakers }\end{array}$ & $\sim 15 \%$ & $\sim 20 \%$ & $\sim 40 \%$ & $\sim 50 \%$ & $\sim 95 \%$ \\
\hline \multirow[t]{5}{*}{ b. } & \multirow{5}{*}{$\begin{array}{l}\text { Status } \\
\text { planning } \\
\text { \& corpus } \\
\text { work }\end{array}$} & Legal recognition & $x$ & $x$ & $x$ & $x$ & $\sqrt{ }$ \\
\hline & & Standard orthography & $x$ & $x$ & $x$ & $\sqrt{ } / x$ & $\sqrt{ }$ \\
\hline & & Medium of instruction & $x$ & $x$ & $x$ & $x$ & $x$ \\
\hline & & School subject & $x$ & $x$ & $x$ & $x$ & $\sqrt{ }$ \\
\hline & & $\begin{array}{l}\text { Description/ } \\
\text { documentation }\end{array}$ & $\sqrt{ }$ & $\sqrt{ }$ & $\sqrt{ }$ & $\sqrt{ }$ & $\sqrt{ }$ \\
\hline \multirow[t]{7}{*}{ c. } & \multirow{7}{*}{$\begin{array}{l}\text { Domains } \\
\text { of use }\end{array}$} & Creative literature & $x$ & $x$ & $\sqrt{/ x}$ & $\sqrt{/ x}$ & $\sqrt{ }$ \\
\hline & & Religion, written \& oral & $x$ & $x$ & $\sqrt{ }$ & $\sqrt{ }$ & $\sqrt{ }$ \\
\hline & & Grass-roots education & $x$ & $x$ & $\sqrt{ }$ & $\sqrt{ }$ & $\sqrt{ }$ \\
\hline & & Political campaigning & $x$ & $x$ & $\sqrt{ }$ & $\sqrt{ }$ & $\sqrt{ }$ \\
\hline & & TV/Radio broadcasting & $x$ & $x$ & $\sqrt{ }$ & $\sqrt{ }$ & $\sqrt{ }$ \\
\hline & & Pop music & $x$ & $\sqrt{ }$ & $\sqrt{ }$ & $\sqrt{ }$ & $\sqrt{ }$ \\
\hline & & TV/Radio/advertising & $x$ & $\sqrt{ }$ & $\sqrt{ }$ & $\sqrt{ }$ & $\sqrt{ }$ \\
\hline
\end{tabular}

and Nigerian Pidgin share the plight of all other AECs save Krio, namely the lack of any status and corpus planning, however modest, by the state.

Ghanaian Pidgin occupies an intermediate position between Nigerian Pidgin and Cameroon Pidgin on the one hand, and Pichi on the other. Contrary to Pichi, Ghanaian Pidgin has no native speaker community. The lack of any institutionally driven form of status or corpus planning therefore represents less of a "reality gap" than the absence of any form of institutional support for Pichi with its well-established native speaker community. The only other language to serve as an "ethnic community language" besides Pichi is Krio. The difference between this characteristic and the one in the first line ("L1 community") lies in the fact that Pichi and Krio are perceived in Equatorial Guinea and Sierra Leone respectively as the primary languages or L1s of specific ethno-linguistic communities (the Krio people in Sierra Leone and the Fernandino and Bubi peoples in Equatorial Guinea). Although there are large and growing L1 communities of Nigerian Pidgin and Cameroon Pidgin as well, these languages do not serve as markers of ethnic identity. These languages are therefore still primarily considered to be lingua francas 
without highly visible native speaker communities. At the same time, all five languages, including Pichi, have more L2 than L1 speakers, a fact that is indicative of the dramatic expansion of these languages since their emergence.

Other than that, the sociolinguistic characteristics of Pichi and Krio could not be more dissimilar, despite them being the two most closely related languages in Table 2. Krio is the only AEC to have been the subject of considerable status planning and corpus work, whether initiated by state institutions or through private and academic initiative. All other languages are characterised by less activity in this regard, and Pichi once more features the least activity even if Pichi and Nigerian Pidgin feature the most extensive grammatical descriptions to-date of any West African AEC (Yakpo 2009a, 2019; Faraclas 1996).

On the whole, Pichi appears as the West African AEC with the lowest status although it serves as an important L1 in Equatorial Guinea. The most striking aspect of the marginalisation of Pichi is its conspicuous absence, some exceptions notwithstanding, from relatively unregulated domains such as pop music, advertising and (private) broadcasting, domains in which the other West African AECs have made their greatest advances. Even Ghanaian Pidgin, which does not function as an L1 nor extensively as a lingua franca, surpasses Pichi in the number of domains in which it is used. However, Equatorial Guinea is generally characterised by the lack of an organised state response to linguistic diversity within its borders. The country has the most profoundly exoglossic language policy in the region, with reliance on the European colonial language Spanish in all but the most informal domains.

Overall, the discrepancies between the status and actual uses of the West African AECs leaves the impression that the potential of these languages remains untapped by official policies across the region for education, political participation, economic activity and cultural production. African countries record some of the lowest literacy rates, the highest school dropout rates, and the lowest tertiary education rates in the world in spite of some of the highest per capita investments in education in relation to GDP (UNESCO 2018; The World Bank 2018).

At least part of this predicament has been attributed to the continuing predominance of European colonial languages as languages of instruction and literacy (see, e.g., the contributions in Baldauf \& Kaplan 2004, 2007). The cognitive advantages of employing African languages for education have been amply demonstrated by study upon study in the last five decades (cf. Brock-Utne 2010). Contrary to received opinion in West Africa, the AECs might have the additional advantage, if used as languages of instruction, of facilitating the acquisition of standard Englishes due to lexical affinities between the two languages, and their often seemless integration in codemixing. The potential benefits of using AECs and other African languages for civic and health communication, the interaction of citizens with administrative 
institutions, political campaigning, in the courtroom and for legal for practice for the construction of more transparent and participatory political cultures are almost self-evident. Less fast-lived forms of cultural production beyond pop music and cinema, like literary production and drama could be reinvigorated. This would, however, require concerted efforts at corpus and status planning, ideally involving the exchange of knowledge, experiences and practices between the countries in which the AECs are spoken. In coming decades, the AECs are also likely to contribute significantly to language contact and change, and become the target of language shift from other African languages spoken in the cities and in rural areas with a high density of smaller languages (e.g. in the Niger Delta federal states of Nigeria or in the Cameroonian Grassfields region). If linguistic diversity is to be maintained and nurtured in the future, this will make structured and concerted approaches to the status and uses of the AECs all the more important.

\section{Conclusion}

The West African AECs facilitate communication across national, regional and ethnic boundaries in a culturally and linguistically highly diverse part of the world. Various socio-cultural factors contribute to the expansion these languages have seen in the last few decades: the AECs are first and foremost languages of the city, and therefore have the lustre of urban life; they serve as youth sociolects in a region with the youngest population on earth; embody a tolerance for variation as well as ethnic indeterminacy and openness; and symbolise and express in their dynamism, adaptability and spatial distribution the African experience of the 21 st century, characterised by rapid socio-economic and cultural change, and accelerated urbanisation.

The expansion of the AECs has taken place despite administrative and insti-tutional practices ranging from inertia and indifference (e.g. Equatorial Guinea), to hostility (e.g. the banning of Cameroon Pidgin in secondary and tertiary ed-ucation institutions). The absence of, or negative state responses to the AECs is the consequence of a complex constellation of economic and political factors that other African languages are also subjected to. Ideological factors also play a significant role innegative attitudes of sections of the elites and decision makers vis-à-vis the AECs. Languages like Nigerian Pidgin and Cameroon Pidgin are still widely seen as forms of "broken English" without grammatical structure and unfit for use other than in the streets.

In spite of the lack of state support in all five countries, the utility of these languages for communication and their identitarian appeal have nevertheless led 
to their conquest of new domains. The increased presence of these languages in the public sphere and in the media is contributing to shifts in language attitudes. The AECs can count on a growing language loyalty of the younger generations. This might be an epiphenomenon of an increasing desire of young of Africans to forge and enact a distinctly "glocal" identity of their own. With their rootedness in local linguistic practices and simultaneous international references the AECs are particularly suited to express the Lebensgefühl of African modernity. The African AECs will therefore continue expanding their domains and social functions with or without state support, thereby forcing language policy choices on decision makers and language stakeholders nolens volens.

\section{Acknowledgements}

I am grateful to two anonymous reviewers for their comments and suggestions for improvement, as well as valuable input from the audience during a talk given at the West African Languages Congress \& Linguistics Association of Ghana Conference 2017 in Winneba, Ghana. This chapter contains material from Yakpo 2016b.

\section{Funding}

I herewith acknowledge the support of grant no. 17608819 of the Research Grants Council of the Government of Hong Kong.

\section{References}

Adegbija, E. 2004. Language policy and planning in Nigeria. Current Issues in Language Planning 5(3): 181-246.

Agheyisi, R. N. 1988. The standardization of Nigerian Pidgin English. English World-Wide 9(2): 227-241. https://doi.org/10.1075/eww.9.2.06agh

Alobwede D’ Epie, C. 1998. Banning Pidgin English in Cameroon? English Today 14(1): 54-60. https://doi.org/10.1017/S0266078400000742

Anchimbe, E. A. 2013. Language Policy and Identity Construction: The Dynamics of Cameroon's Multilingualism [Impact: Studies in Language and Society 32]. Amsterdam: John Benjamins. https://doi.org/10.1075/impact.32

Anonymous. 1984. Revised Kono, Krio, Limba, Mende and Themne Orthographies - Workshop Held during April 24-27, 1984. Freetown, Sierra Leone: Ministry of Education.

Arends, J., Muysken, P. C. \& Smith, N. S. H. (eds). 1995. Pidgins and Creoles: An Introduction [Creole Language Library 15]. Amsterdam: John Benjamins. https://doi.org/10.1075/cll.15

Asociación Cristiana de Traducciones Biblicas. n.d. Kálara Nzamá Fay Guinea Ecuatorial. Bata: n.p. 
Ayafor, M. \& Green, M. J. 2017. Cameroon Pidgin English: A Comprehensive Grammar [London Oriental and African Language Library 20]. Amsterdam: John Benjamins. https://doi.org/10.1075/loall.20

Bakker, P. 2008. Pidgins versus creoles and pidgincreoles. In The Handbook of Pidgin and Creole Studies, S. Kouwenberg \& J. V. Singler (eds), 130-57. Oxford: Blackwell.

Baldauf, R. B. \& Kaplan, R. B. 2004. Language Planning and Policy in Africa, Vol. 1. Clevedon: Multilingual Matters.

Baldauf, R. B. \& Kaplan, R. B. 2007. Language Planning and Policy in Africa, Vol. 2. Clevedon: Multilingual Matters.

Berry, J. 1961. English loanwords and adaptations in Sierra Leone Krio. In Creole Language Studies II, R. B. le Page (ed.), 1-16. London: Macmillan.

Bible Society in Sierra Leone. 2013. Krio fos oli Baybul.

Bolekia Boleká, J. 2005. La francofonía: El nuevo rostro del colonialismo en África. Salamanca: Signum S.G.E.

Brock-Utne, B. 2010. Research and policy on the language of instruction issue in Africa. International Journal of Educational Development 30(6): 636-645.

Corum, M. 2015. Substrate and Adstrate: The Origins of Spatial Semantics in West African Pidgincreoles. Berlin: De Gruyter Mouton.

Crevels, M. \& Muysken, P. C. (eds). 2009. Lenguas de Bolivia, 4 Vols. La Paz: Plural editores.

Dako, K. 2002. Student Pidgin (SP): The language of the educated male elite. Research Review from the Institute of African Studies (IAS), University of Ghana 18(2): 53-62.

Dako, K. 2013. Student Pidgin: A masculine code encroached on by young women. In Gender and Language in Sub-Saharan Africa: Tradition, Struggle and Change [Impact: Studies in Language and Society 33], L. L. Atanga, S. E. Ellece, L. Litosseliti \& J. Sunderland (eds), 217-231. Amsterdam: John Benjamins. https://doi.org/10.1075/impact.33

Decker, T. 1988. Juliohs Siza. Edited by N. Shrimpton and N. Sulayman, Vol. 4 [Krio Publications Series]. Umeå: Umeå University.

Devonish, H. 1986. Language and Liberation: Creole Language Politics in the Caribbean. London: Karia Press.

Devonish, H. 2010. The language heritage of the Caribbean: Linguistic genocide and resistance. Glossa 5(1): 1-26.

Faraclas, N. G. 2004. Nigerian Pidgin English: Morphology and syntax. In A Handbook of Varieties of English, Vol 2: Morphology and Syntax, B. Kortmann, E. W. Schneider, K. Burridge, T. Mesthrie \& C. Upton (eds), 828-853. Berlin: Mouton de Gruyter.

Faraclas, N. G. 1996. Nigerian Pidgin. London: Routledge.

Faraclas, N. G. 2013. Nigerian Pidgin. In The Survey of Pidgin and Creole Languages: Englishbased and Dutch-based Languages, S. Michaelis, P. Maurer, M. Haspelmath \& M. Huber (eds), 176-184. Oxford: OUP. <https://apics-online.info/surveys/17> (9 June 2020).

Faraclas, N. G. 1986. Reading and Writing Nigerian Pidgin. Port Harcourt: Rivers Readers Project (RRP).

Finney, M. A. 2011. Krio (Sierra Leone Creole). In Electronic World Atlas of Varieties of English, Bernd Kortmann \& Kerstin Lunkenheimer (eds). Leipzig: Max Planck Institute for Evolutionary Anthropology. <http://ewave-atlas.org/languages/36> (23 April 2020).

Finney, M. A. 2013. Krio. In The Survey of Pidgin and Creole Languages: English-based and Dutchbased Languages, S. Michaelis, P. Maurer, M. Haspelmath \& M. Huber (eds), 1:157-166. Oxford: OUP. <https://apics-online.info/surveys/15> (23 April 2020). 
Fonka, H. M. 2016. Is Cameroon Pidgin English a pidgin, a pidgincreole or a creole? Yaoundé. Fyle, C. N. \& Jones, E. D. 1980. A Krio-English Dictionary. Oxford: OUP.

Gani-Ikilama, T. O. 1990. Use of Nigerian Pidgin in education: Why not? In Multilingualism, Minority Languages and Language Policy in Nigeria, E. N. Emenanjo (ed.), 219-227. Agbor, Nigeria: Central Books.

Gift, A. 2019. Romeo and Juliet don land for pidgin. BBC News Pidgin, July 4, 2019, sec. Tori. $<$ https://www.bbc.com/pidgin/media-48851624> (26 September 2019).

Hancock, I. F. 1971. A Study of the Sources and Development of the Lexicon of Sierra Leone Krio. PhD dissertation, University of London.

Hancock, I. F. 1987. A preliminary classification of Anglophone Atlantic creoles, with syntactic data from thirty-three representative dialects. In Pidgin and Creole Languages: Essays in Memory of John Reinecke, G. G. Gilbert (ed.), 264-333. Honolulu HI: University of Hawai'i Press.

Heine, B. 1992. Language policies in Africa. In Language and Society in Africa: The Theory and Practice of Sociolinguistics, R. K. Herbert (ed), 23-35. Johannesburg: Witwatersrand University Press.

Huber, M. 1995. Ghanaian Pidgin English: An overview. English World-Wide 16(2): 215-249. https://doi.org/10.1075/eww.16.2.04hub

Huber, M. 1999. Ghanaian Pidgin English in Its West African Context: A Sociohistorical and Structural Analysis [Varieties of English Around the World G24]. Amsterdam: John Benjamins. https://doi.org/10.1075/veaw.g24

Huber, M. 2000. Restructuring in vitro? Evidence from early Krio. In Degrees of Restructuring in Creole Languages [Creole Language Library 22], I. Neumann-Holzschuh \& E. W. Schneider (eds), 275-307. Amsterdam: John Benjamins. https://doi.org/10.1075/cll.22

Huber, M. 2013. Ghanaian Pidgin English. In The Survey of Pidgin and Creole Languages: English-based and Dutch-based Languages, S. Michaelis, P. Maurer, M. Haspelmath \& M. Huber (eds), 1:167-175. Oxford: OUP. <https://apics-online.info/surveys/16> (23 April 2020).

Huber, M. \& Görlach, M. 1996. West African Pidgin English. English World-Wide 17(2): 239-258. https://doi.org/10.1075/eww.17.2.07hub

Igboanusi, H. 2008. Empowering Nigerian Pidgin: A challenge for status planning? World Englishes 27(1): 68-82. https://doi.org/10.1111/j.1467-971X.2008.00536.X

Ihemere, K. U. 2006. A basic description and analytic treatment of noun clauses in Nigerian Pidgin. Nordic journal of African Studies 15(3): 296-313.

Jones, E. D. 1968. Some tense, mode and aspects markers in Krio. African Language Review 7: 86-89.

Juffermans, K. \& McGlynn, C. 2010. A sociolinguistic profile of The Gambia. Sociolinguistic Studies 3(3): 329-355.

Kouega, J.-P. 2008. A Dictionary of Cameroon Pidgin English Usage: Pronunciation, Grammar and Vocabulary [Lincom Studies in Pidgin \& Creole Linguistics 9]. Munich: Lincom.

Lewis, M. P., Simons, G. F. \& Fennig, C. D. (eds). 2013. Ethnologue: Languages of the World. Dallas TX: SIL International. <http://www.ethnologue.com> (30 May 2013).

Lipski, J. M. 1992. Pidgin English usage in Equatorial Guinea (Fernando Poo). English WorldWide 13(1): 33-57. https://doi.org/10.1075/eww.13.1.03lip

Lynn, M. 1984. Commerce, christianity and the origins of the "Creoles" of Fernando Po. The Journal of African History 25(3): 257-278.

Mbangwana, P. 1983. The scope and role of Pidgin English in Cameroon. In A Sociolinguistic Profile of Urban Centers in Cameroon, E. L. Koenig, E. N. Chia \& J. F. Povey (eds), 79-92. Los Angeles CA: Crossroad Press. 
Molindo, E. A. 1996. Cameroon Pidgin Bible. Yaoundé: n.p.

Momoh, A. \& Adejumobi, S. 2002. The National Question in Nigeria: Comparative Perspectives. Aldershot Burlington: Ashgate.

Morgades Besari, T. 2011. Los criollos (Fernandinos-Kriös) de Guinea Ecuatorial. La Gaceta de Guinea Ecuatorial, April 2011, No. 162 edition, sec. Misceláneas.

Muysken, P. C. (ed.). 1981a. Generative Studies on Creole Languages [Studies in Generative Grammar 6]. Dordrecht: Foris.

Muysken, P. C. 1981b. Halfway between Quechua and Spanish: The case for relexification. In Historicity and Variation in Creole Studies, A. Valdman \& A. Highfield (eds), 52-78. Ann Arbor MI: Karoma.

Muysken, P. C. (ed.). 2008. From Linguistic Areas to Areal Linguistics [Studies in Language Companion Series 90]. Amsterdam: John Benjamins. https://doi.org/10.1075/slcs.90

Muysken, P. C. \& Smith, N. S. H. (eds). 1986. Substrata Versus Universals in Creole Genesis: Papers from the Amsterdam Creole Workshop, April 1985 [Creole Language Library 1]. Amsterdam: John Benjamins. https://doi.org/10.1075/cll.1

Muysken, P. C. \& Smith, N. S. H. (eds). 2015. Surviving the Middle Passage: The West Africa-Surinam Sprachbund [Trends in Linguistics, Studies and Monographs (TiLSM) 275]. Berlin: De Gruyter Mouton.

Neba, A. N., Chibaka, E. F. \& Atindogbé, G. 2006. Cameroon Pidgin English (CPE) as a tool for empowerment and national development. African Study Monographs 27: 39-61.

Newman, P. 1987. Hausa and the Chadic languages. In The World's Major Languages, B. Comrie (ed.), 705-723. Oxford: OUP.

Ngefac, A. 2010. Linguistic choices in postcolonial multilingual Cameroon. Nordic Journal of African Studies 19(3): 149-164.

Ngefac, A. 2016. Sociolinguistic and Structural Aspects of Cameroon Creole English. Newcastle upon Tyne: Cambridge Scholars.

Nkengasong, N. 2016. A Grammar of Cameroonian Pidgin. Newcastle upon Tyne: Cambridge Scholars.

Nordén, A. H. 2016. Epistemic Modality in Ghanaian Pidgin English. MA thesis, University of Stockholm. <http://www.diva-portal.org/smash/get/diva2:940706/FULLTEXT01.pdf> (26 September 2019).

Ojarikre, A. 2013. Perspectives and problems of codifying Nigerian Pidgin English orthography. Developing Country Studies 3(12): 126-133.

Osei-Tutu, K. O. A. 2008. Exploring Meaning in Students' P(SP). MPhil thesis, University of Ghana, Legon.

Osei-Tutu, K. O. A. 2016. Lexical borrowing in Ghanaian Student Pidgin (GSP) - The case of Akan loanwords and loan translations. In Celebrating Multiple Identities: Opting out of Neocolonial Monolinguism, Monoculturalism and Mono-identification in the Greater Caribbean, N. Faraclas, R. Severing, C. Weijer, E. Echteld, W. Rutgers \& R. Dupey (eds), 47-54. Willemstad: University of Curaçao and Fundashon pa Planifikashon di Idioma.

Perrois, L. 1972. La statuaire Fang, Gabon. Paris: O.R.S.T.O.M.

Schröder, A. 2003. Status, Functions, and Prospects of Pidgin English: An Empirical Approach to Language Dynamics in Cameroon. Tübingen: Gunter Narr.

Smith, N. S. H. 2015. Ingredient X: The shared African lexical element in the English-lexifier Atlantic Creoles, and the theory of rapid creolization. In Surviving the Middle Passage: The West Africa-Surinam Sprachbund [Trends in Linguistics, Studies and Monographs (TiLSM) 275], P. C. Muysken \& N. S. H. Smith (eds), 67-106. Berlin: De Gruyter Mouton. 
The World Bank. 2018. Education statistics. World Bank Open Data, 2018. <http://datatopics. worldbank.org/education/> (4 April 2018).

UNESCO. 2018. Global Education Monitoring Report. 2017/8 GEM Report - Accountability in Education: Meeting Our Commitments, 2018. <https://en.unesco.org/gem-report/statistics> (4 April 2018).

United Nations. 2017. World population prospects: The 2017 revision, key findings and advance tables [Working Paper ESA/P/WP/248]. New York: United Nations Department of Economic and Social Affairs, Population Division. <https://population.un.org/wpp/Publications/Files/WPP2017_KeyFindings.pdf> (24 April 2020).

van Sluijs, R., van den Berg, M. C. \& Muysken, P. C. 2016. Exploring genealogical blends: The Surinamese Creole cluster and the Virgin Island Dutch Creole cluster. Lingua 178: 84-103. https://doi.org/10.1016/j.lingua.2015.12.004

Vydrin, V. 2013. Bamana Reference Corpus (BRC). Procedia - Social and Behavioral Sciences 95: 75-80. https://doi.org/10.1016/j.sbspro.2013.10.624

Wyse, A. J. G. 1991. The Krio of Sierra Leone: An Interpretive History. Washington DC: Howard University Press.

Yakpo, K. 2009a. A Grammar of Pichi. PhD dissertation, Radboud University Nijmegen. https://doi.org/10.5281/zenodo.3740353> (27 March 2020).

Yakpo, K. 2009b. Complexity revisited: Pichi (Equatorial Guinea) and Spanish in contact. In Simplicity and Complexity in Creoles and Pidgins, N. G. Faraclas \& T. Klein (eds), 183-215. London: Battlebridge.

Yakpo, K. 2010. Gramática del Pichi [Laboratorio de Recursos Orales 13]. Barcelona: Ceiba Ediciones.

Yakpo, K. 2012a. Betwixt and between: Causatives in the English-lexicon creoles of West Africa and the Caribbean. In Analytical Causatives: From "Make" to "Laskma", J. Leino \& R. von Waldenfels (eds), 9-39. Munich: Lincom.

Yakpo, K. 2012b. Reiteration in Pichi: Forms, functions and areal-typological perspectives. In The Morphosyntax of Reiteration in Creole and Non-creole Languages [Creole Language Library 43], E. O. Aboh, N. S. H. Smith \& A. Zribi-Hertz (eds), 251-284. Amsterdam: John Benjamins. https://doi.org/10.1075/cll.43.08yak

Yakpo, K. 2013a. Pichi. In The Atlas of Pidgin and Creole Language Structures: English-based and Dutch-based Languages, S. Michaelis, P. Maurer, M. Haspelmath \& M. Huber (eds), 1:194-205. Oxford: OUP. <http://apics-online.info/contributions/19> (2 March 2018).

Yakpo, K. 2013b. Wayward daughter: Language contact in the emergence of Pichi (Equatorial Guinea). Journal of African Languages and Linguistics 34(2): 275-299. https://doi.org/10.1515/jall-2013-0009

Yakpo, K. 2016a. O estatuto do pichi na Guiné Equatorial. PLATÔ (Revista Digital do Instituto Internacional da Língua Portuguesa), Glotopolítica na Guiné Equatorial 3(6): 20-40.

Yakpo, K. 2016b. “The only language we speak really well”. The English creoles of Equatorial Guinea and West Africa at the intersection of language ideologies and language policies. In Exploring Glottopolitical Dynamics in Africa: The Spanish Colonial Past and Beyond, S. Castillo-Rodríguez \& L. Morgenthaler García (eds). Special issue of International Journal of the Sociology of Language 239: 211-233. https://doi.org/10.1515/ijsl-2016-0010

Yakpo, K. 2017. Towards a model of language contact and change in the English-lexifier creoles of Africa and the Caribbean. English World-Wide 38(1): 50-76.

https://doi.org/10.1075/eww.38.1.04yak 
Yakpo, K. 2018. ¿El nacimiento de una lengua afrohispana?: La influencia del español en el idioma criollo inglés de Guinea Ecuatorial. In Trans-afrohispanismos: Puentes culturales críticos entre África, Latinoamérica y España [Foro Hispánico 58], D. Odartey-Wellington (ed.), 243-259. Leiden: Brill. https://doi.org/10.1163/9789004364080_015

Yakpo, K. 2019. Inheritance, contact, convergence: Pronominal allomorphy in the African English-lexifier Creoles. English World-Wide 40(2): 201-225. https://doi.org/10.1075/eww.00028.yak

Yakpo, K. \& Muysken, P. C. (eds). 2017. Boundaries and Bridges: Language Contact in Multilingual Ecologies [Language Contact and Bilingualism 14]. Berlin: De Gruyter Mouton. https://doi.org/10.1515/9781614514886

Yankson, S. 2018. Language Contact and Change in Linguistically Heterogeneous Urban Communities. The Case of Akan in Accra. PhD dissertation, Radboud University Nijmegen.

de Zarco, Mariano. 1938. Dialecto Inglés-Africano o Broken-English de La Colonia Española Del Golfo de Guinea. Turnhout, Belgium: H. Proost. 